\title{
Article \\ Molecular Dynamics Study on the Crystallization Process of Cubic Cu-Au Alloy
}

\author{
Tuan Tran Quoc ${ }^{1}\left(\mathbb{D}\right.$, Van Cao Long ${ }^{2}$, Ştefan Ţălu ${ }^{3, *(\mathbb{C})}$ and Dung Nguyen Trong ${ }^{2,4, *(\mathbb{D})}$ \\ 1 Faculty of Basic Science, University of Transport Technology, 54 Trieu Khuc, Thanh Xuan, \\ Hanoi 100000, Vietnam; tranquoctuan1181@gmail.com \\ 2 Institute of Physics, University of Zielona Góra, Prof. Szafrana 4a, 65-516 Zielona Góra, Poland; \\ caolonganuz@gmail.com \\ 3 The Directorate of Research, Development and Innovation Management (DMCDI), \\ Technical University of Cluj-Napoca, 15 Constantin Daicoviciu St., 400020 Cluj-Napoca, Romania \\ 4 Faculty of Physics, Hanoi National University of Education, 136 Xuan Thuy, Cau Giay, Hanoi 100000, Vietnam \\ * Correspondence: stefan_ta@yahoo.com (Ş.Ţ.); dungntdt2018@gmail.com (D.N.T.)
}

check for updates

Citation: Quoc, T.T.; Long, V.C.; Ţălu,

Ş.; Nguyen Trong, D. Molecular

Dynamics Study on the

Crystallization Process of Cubic

$\mathrm{Cu}-\mathrm{Au}$ Alloy. Appl. Sci. 2022, 12, 946.

https://doi.org/10.3390/

app12030946

Academic Editor: Sérgio F. Sousa

Received: 16 December 2021

Accepted: 13 January 2022

Published: 18 January 2022

Publisher's Note: MDPI stays neutral with regard to jurisdictional claims in published maps and institutional affiliations.

Copyright: (C) 2022 by the authors. Licensee MDPI, Basel, Switzerland. This article is an open access article distributed under the terms and conditions of the Creative Commons Attribution (CC BY) license (https:// creativecommons.org/licenses/by/ $4.0 /)$.

\begin{abstract}
In this study, molecular dynamics simulations have been used to study the influencing factors, such as the time of each heating step, temperature, and annealing time, on the structure and crystallization process of $\mathrm{Cu}-\mathrm{Au}$ alloy. The results show that when the temperature increased, the crystallization process decreased, and the structure gradually turns to the liquid state, and vice versa. When increasing the time of each heating step and the annealing time, the crystallization process increased, then increased the most at the glass temperature, $\mathrm{T}_{\mathrm{g}}=550 \mathrm{~K}$. During the phase transition, link length $(r)$, total energy $\left(E_{\text {tot }}\right)$, size $(\mathrm{l})$, number of FCC, HCP, and Amor structural units have a significant change. The obtained results of $\mathrm{Cu}-\mathrm{Au}$ alloy can serve as a basis for future experimental studies.
\end{abstract}

Keywords: annealing time; crystallization process; $\mathrm{Cu}-\mathrm{Au}$ alloy; molecular dynamics; structure

\section{Introduction}

The quantum description of a large, multi-component physical system is usually complex, and its implementation is frequently impossible even for today's supercomputers. In addition, this quantum description often obscured the physical picture of the phenomena under consideration. Therefore, approximate simulations, based on the probabilistic treatment of the system, with parameters included in the problem after their quantum averaging, are often used, where the involved physical quantities are already treated as random variables or classical stochastic processes, and further numerical simulations are carried out using classical equations. This approach was used initially in the 1950s and then intensively developed in the 1980s, widely used now in the theory of solids, chemistry, and molecular biology. One of these is the so-called Molecular Dynamics (MD) method. This method is the most popular in the microscopic analysis [1]. In the framework of MD simulation, Newtonian equations of motion are used with the initial conditions generated randomly. We would like to emphasize here that our publication analyzing the classical model of ionization for two-electron atoms in intense laser beam, described in [2], can be considered as one of the first precursors of the MD method. This model has been demonstrated in detail in [3]. In this model, we started with a random generation of the initial conditions for positions and momenta of electrons by the Monte Carlo (MC) method by a modified Wigner Distribution in Phase Space. Then, the classical Newtonian equations of electrons were integrated. After that, all quantities related to the problem were averaged with the new distribution function created by new points in the phase space of electrons in the given time, $t$. It follows that the obtained results were in satisfactory agreement with experimental observations. In practice, a real physical system consists of a large number of elements. Therefore, the MD simulation stays a unique possible tool for microscopic analysis level. In this paper, MD simulation was used. In the 
framework of MD simulation, some aspects should be carefully considered. First of all, the stability of the calculation code is or is not guaranteed with the choice of both numbers of constituents and the number of performed calculations steps. Furthermore, such problems as sensitive dependence of initial conditions leading to chaos, the accuracy of integration method for large system of nonlinear partial differential equations, etc., should be analyzed [4]. In practice, we use a phenomenological criterion for the validity of obtained results: when they are in good agreement with a large class of experimental results obtained before by numerous authors, they can be accepted as satisfied ones. Finally, the most essential aspect of the MD simulation procedure is the suitable choice of pair interaction between involved constituents. In a recent paper, the potential embedded in the simulation was chosen as Sutton-Chen (SC) type with free boundary conditions. We discuss this choice below. The subject of our recent considerations was the $\mathrm{Cu}-\mathrm{Au}$ alloy. It is a material comprising of two metals, $\mathrm{Cu}$ and $\mathrm{Au}$, with a cubic structure. $\mathrm{Cu}$ is a metal with high electrical conductivity and ductility, it can oxidize when it is exposed to the environment, and the reduction process from alcohol to aldehyde $[5,6]$ is also a catalyst $[7,8]$. Au is a metal that is very stable for chemical reactions, has very good oxidation resistance, and is considered a heterogeneous substance [9]. When the size of the Au material is decreased to the nanometer size, the photocatalytic activity increased significantly [10].

Many researchers have studied the mechanism of $\mathrm{CO}$ oxidation at lower ambient temperatures [11-13]. $\mathrm{Cu}-\mathrm{Au}$ alloys also were used in photocatalytic applications, such as methanol production [14,15], oxidation reactions [16], and organic compounds [17]. There are many methods to research and fabricate $\mathrm{Cu}-\mathrm{Au}$ alloys, such as theoretical methods, experimental methods, and simulation methods. In particular, experimental methods, including chemical methods, have determined that $\mathrm{Cu}-\mathrm{Au}$ alloys depend not only on the size but also depend on the ratio between gold and copper. The X-ray method has determined the X-ray diffraction spectral structure and the energy of valence electrons of $\mathrm{Cu}_{3} \mathrm{Au}$ and $\mathrm{Cu}-\mathrm{Au}_{3}$ alloys in the ordered and unordered states [18]. Simulation methods include: the colloidal model [19], the Finnis-Sinclair model (FS) [20], the Embedded Atom Method (EAM) [21], and the Sutton-Chen (SC) model [22] potential and Slag Models Approximation (SMA) (with the Tightly Bound (TB) model [23]).

The simulation method was considered a semi-empirical method and was applied in studies of structural properties of metals and alloys [23-26] through the atomic force field [27-30], as well as in studies of structural phase transitions in metals and alloys, based on the potential field parameters from the components of the pure atom [27-31]. For specific applications, it is necessary to perform some approximations to determine the properties of materials, such as link length, lattice constant, energy, and phase transition temperature [32]. Additionally, theoretical models, based on quantum calculations, are applied to determine the parameters of the simulation model, in different studies about the structural properties, phase transitions, and crystallization of alloys [33]. Many researchers have successfully used the potential field of Rafii-Tabar and Sutton-Chen (SC) [21] to study the binary Face-Centered Cubic (FCC) structure for the alloy without changing the original elemental parameters [21,34]. The SC potential belongs to the class of optimized Embedded Atom Method (EAM), where the energy of the considered system is calculated by embedding a given atom in the local density field of electrons created by the other atoms surrounding it. The parameters of SC potential are fixed by fitting first principles and experimental data for $\mathrm{Cu}, \mathrm{Au}$, and $\mathrm{Cu}-\mathrm{Au}$ binary compounds, such as the lattice parameter, cohesive energy, bulk modulus, elastic constants, and phonon dispersion curves, tested for accurate values of surface energies, etc. The simple power law of the SC potential gives us a faster numerical algorithm than in the case of general EAM. Furthermore, scientists [35] reconstructed the Sutton-Chen (SC) potential by adding quantities, such as phonon frequency and zero energy, and called this new interaction the potential Quantum Sutton-Chen (Q-SC) [36-40]. Cu-Au alloys are also applied in lower $\mathrm{CO}$ oxidation than pure metals [41]. It is known that the catalytic activities of the materials determined through the surface effect strongly depend on the structural properties [42-44]. In some studies, the energies of $\mathrm{Cu}, \mathrm{Au}$, and $\mathrm{Cu}-\mathrm{Au}$ metals, were determined by the EAM 
force field [45] with $\mathrm{Cu}_{3} \mathrm{Au}$ [46]. However, the crystallization of $\mathrm{Cu}-\mathrm{Au}$ alloy occurs more easily than that of $\mathrm{Cu}_{3} \mathrm{Au}$ [47]. Based on these studies, it can be specified that there is a major influence of the structure on the mechanical properties of $\mathrm{Cu}-\mathrm{Au}$ [48] and the properties of $\mathrm{Cu}-\mathrm{Au}[49,50]$. In addition, the effect of anisotropy on the deformation process has been found to have a nonlinear symmetry at low temperatures [51]. Morse interaction potential is widely used in the process of studying defects and deformation of metals and alloys [52,53]. Several studies revealed the $\mathrm{Cu}$-Au alloy is a binary alloy that survives temperature-induced transformation and is stable long term, with a super-cohesive structure [54-58]. In addition, the phase transition of $\mathrm{Cu}-\mathrm{Au}$ alloy follows the type I phase transition such as $\mathrm{T}>683 \mathrm{~K}$, having face-centered cubic (FCC) structure, $\mathrm{T}<543 \mathrm{~K}$ exist a tetragonal structure, and for $543 \mathrm{~K}<\mathrm{T}<683 \mathrm{~K}$ there is a phase transition temperature range [59]. Scientists observed in the phase transition temperature region a decrease in the $\mathrm{Cu}$-Au gravity $[48,60,61]$. Previous studies have shown the fine-tuning of the catalytic activity of Au nanoparticles $[62,63]$. The plasmonic response of $\mathrm{Cu}-\mathrm{Au}$ nanocrystals with low $\mathrm{Cu}$ content has also been used in photochemotherapy [62], and a tunable plasmon response is also predicted for precious metals [64]. Recently, researchers studied the 2D structure of $\mathrm{Au}$ at an evaporation temperature of $\mathrm{T}_{\mathrm{m}}=1353 \mathrm{~K}$ directly on graphene films containing $\mathrm{Cu}$ from the growth of the base material. Under electron irradiation, $\mathrm{Au}$ atoms are liberated and bound to the $\mathrm{Cu}$ substrate to form $\mathrm{Cu}-\mathrm{Au}$ alloys [33]. Scientist have also successfully studied the electronic structure, phase transition, and crystallization of $\mathrm{Al}$ [65], Fe [66], AlNi nanoparticles [67], NiCu bulk [68], $\mathrm{NiFe}$ nanoparticle [69], AgAu alloy [70], NiCu nanoparticle [71], $\mathrm{AuCu}$ bulk [72], NiAu alloy [73], and polymer [74]. In particular, with $\mathrm{NiCu}$ and $\mathrm{NiAu}$ alloys, it has been shown that when increasing the temperature and heating rate, the length of the link $r$ decreased, $g(r)$ decreased while increasing the number of atoms, the annealing time increased, then $\mathrm{r}$ and $\mathrm{g}(\mathrm{r})$ increased $[68,71,73]$. From the considerations mentioned above, there appears the following question: if the metals are doped together, can the phenomenon of the length of the links be decreased? To answer that question, we continue to work with $\mathrm{Cu}-\mathrm{Au}$ alloy to elucidate that problem by studying the influence of factors on the structure, crystallization, and phase transition of cubic $\mathrm{Cu}-\mathrm{Au}$. Crystallization rate is the ability of the process to happen quickly or slowly, depending on many factors. We will show that, when the temperature increased, the crystallization process decreased, the structure gradually turns to the liquid state, and vice versa. The consideration of the change of crystallization process is of great significance in determining structural changes and material properties, such as electrical and magnetic properties. As the crystallization process increased, the electrical conductivity and magnetic of the material increase.

When the time of each heating step increased, and the annealing time (the extension of the heating time at each heating step), the crystallization process increased, then it advances the most at the glass temperature $T_{g}=550 \mathrm{~K}$. During the phase transition, link length $(r)$, total energy $\left(E_{\text {tot }}\right)$, size $(1)$, number of FCC, HCP, and Amor structural units have a significant change.

The obtained results are evidence for the research and fabrication of this material for photocatalytic devices in the future.

\section{Method of Calculation}

Initially, we randomly seed $2916 \mathrm{Cu}-\mathrm{Au}$ atoms with a Cu:Au ratio of 1:1, corresponding to $1458 \mathrm{Cu}$ atoms:1458 Au atoms, into a cube of size (l) determined by the following formula:

$$
1=\sqrt[3]{\frac{\mathrm{N}}{\rho}}=\sqrt[3]{\frac{\left(\mathrm{m}_{\mathrm{Cu}} \cdot \mathrm{n}_{\mathrm{Cu}}+\mathrm{m}_{\mathrm{Au}} \cdot \mathrm{n}_{\mathrm{Au}}\right)}{\rho}}
$$

where $\mathrm{l}, \mathrm{N}$ is the size, the number of atoms, $\rho$ is the density of atoms, $\mathrm{m}_{\mathrm{Cu}}, \mathrm{n}_{\mathrm{Cu}}$ is the molar mass atomic, atoms number of $\mathrm{Cu}$ metal, and $\mathrm{m}_{\mathrm{Au}}, \mathrm{n}_{\mathrm{Au}}$ are the same as $\mathrm{Au}$.

Then, the model is placed in the potential field expressed by Equation $(2 a, b)$ and are studied the structural features and phase transitions by molecular dynamics (MD) 
simulations method [75-85], and with embedded Sutton-Chen (SC) interaction [86-94] considering periodic boundary conditions, as follows:

$$
\begin{gathered}
E_{\text {tot }}=\sum_{i=1}^{N} \frac{1}{2} \sum_{j=1, j \neq i}^{N} \Phi\left(r_{i j}\right)+F\left(\rho_{i}\right) \\
\Phi\left(r_{i j}\right)=\varepsilon\left(\frac{a}{r_{i j}}\right)^{n}, F\left(\rho_{i}\right)=-\varepsilon C \sum_{i=1}^{N} \sqrt{\rho_{i}}, \rho_{i}=\sum_{j=1, j \neq i}^{N} \rho\left(r_{i j}\right), \rho\left(r_{i j}\right)=\left(\frac{a}{r_{i j}}\right)^{n}
\end{gathered}
$$

The parameters of the $\mathrm{Cu}-\mathrm{Au}$ alloy are shown in Table $1[92,93]$.

Table 1. Parameters of $\mathrm{Cu}-\mathrm{Au}$ alloy.

\begin{tabular}{cccccc}
\hline Alloy & $\varepsilon\left(\times \mathbf{1 0}^{-\mathbf{2}} \mathbf{e V}\right)$ & $\mathbf{a}(\mathbf{A})$ & $\mathbf{n}$ & $\mathbf{m}$ & $\mathbf{C}$ \\
\hline $\mathrm{Cu}[92,93]$ & 1.239 & 3.615 & 9 & 6 & 39.755 \\
$\mathrm{Au}[92,93]$ & 0.128 & 4.080 & 10 & 8 & 34.408 \\
$\mathrm{Cu}-\mathrm{Au}$ & 0.398 & 3.848 & 9.5 & 7 & 36.985 \\
\hline
\end{tabular}

In this formula: $\mathrm{r}_{\mathrm{ij}}, \mathrm{a}, \rho_{\mathrm{i}}, \mathrm{E}_{\mathrm{tot}}, \rho\left(\mathrm{r}_{\mathrm{ij}}\right), \mathrm{F}\left(\rho_{\mathrm{i}}\right), \varepsilon$ and $\mathrm{m}, \mathrm{n}, \mathrm{C}$ are the distance between two atoms, lattice constant, atomic density, the total energy of the system, density between two atoms, interaction force of atom, energy, and the coefficient, respectively.

The parameters of the $\mathrm{Cu}-\mathrm{Au}$ alloy are determined by the following mathematical Equation $(3 a, b)$ :

$$
\begin{gathered}
\varepsilon_{\mathrm{CuAu}}=\sqrt{\varepsilon_{\mathrm{Cu}} \cdot \varepsilon_{\mathrm{Au}}}, \mathrm{a}_{\mathrm{CuAu}}=\frac{\left(\mathrm{a}_{\mathrm{Cu}}+\mathrm{a}_{\mathrm{Au}}\right)}{2}, \mathrm{n}_{\mathrm{CuAu}}=\frac{\left(\mathrm{n}_{\mathrm{Cu}}+\mathrm{n}_{\mathrm{Au}}\right)}{2} \\
\mathrm{~m}_{\mathrm{CuAu}}=\frac{\left(\mathrm{m}_{\mathrm{Cu}}+\mathrm{m}_{\mathrm{Au}}\right)}{2}, \mathrm{C}_{\mathrm{CuAu}}=\sqrt{\mathrm{C}_{\mathrm{Cu}} \cdot \mathrm{C}_{\mathrm{Au}}}
\end{gathered}
$$

For all samples were applied the following unified procedure. After creating the $\mathrm{Cu}-\mathrm{Au}$ alloy material model, and the samples run a statistical recovery $2 \times 10^{4} \mathrm{MD}$ steps simulation steps so that the atoms do not stick to each other. Then, the temperature was increased from $300 \mathrm{~K}$ to $2000 \mathrm{~K}$ with $17 \times 10^{4} \mathrm{MD}$ steps simulation steps so that the material changes from the initial crystalline state to the liquid state. From the liquid state $\mathrm{T}=2000 \mathrm{~K}$, the temperature of samples lowered to $\mathrm{T}=300 \mathrm{~K}$ so that the material changes to a new crystalline state. To study the effect of time on each heating step, we choose $\mathrm{Cu}-\mathrm{Au}$ material at $\mathrm{T}=300 \mathrm{~K}$, and then it was changed the time of each heating step, with different values, respectively: $h=1.0,1.5,2.0,2.5,3.0$ fs. Similarly, with the influence of heating rate, it was selected $\mathrm{Cu}-\mathrm{Au}$ material at $\mathrm{T}=300 \mathrm{~K}$, and then it was changed the heating rate, with different values, respectively, $4 \times 10^{12} \mathrm{~K} / \mathrm{s}$. Then, the temperature $(\mathrm{T})$ increased from $\mathrm{T}=300 \mathrm{~K}$ to $\mathrm{T}=400,550,600,700,800,1500,2000 \mathrm{~K}$. All calculation processes were determined by the Valet algorithm [95].

To study structure characteristic quantities through structure shape and size (l), the radial distribution function (RDF) is used in Equation (4), as follows:

$$
\mathrm{g}(\mathrm{r})=\frac{\mathrm{V}}{\mathrm{N}^{2}}\left\langle\frac{\sum_{\mathrm{i}} \mathrm{n}_{\mathrm{i}}(\mathrm{r})}{4 \pi \mathrm{r}^{2} \Delta \mathrm{r}}\right\rangle
$$

where: $r, n_{i}(r), V$, and $g(r)$ are the link length, the coordinates, the volume, and the radial distribution function, respectively.

To determine the number of structural units, one can use the Common Neighborhood Analysis (CNA) method [96-102]. The crystallizing process was carried out based on the laws of Nosé et al. [102] and the heating process by Hoover et al. [103]. The techniques of particle size analysis, atomic composition, and configuration were also applied [102]. 


\section{Results and Discussion}

\subsection{Structural Characteristic Quantities}

The crystallization process of $\mathrm{Cu}-\mathrm{Au}$ alloy (at temperature $\mathrm{T}=300 \mathrm{~K}$ with a heating rate of $4 \times 10^{12} \mathrm{~K} / \mathrm{s}$, and a time per heating step of $\mathrm{h}=3 \mathrm{fs}$ ) is shown in Figure 1 .

a)

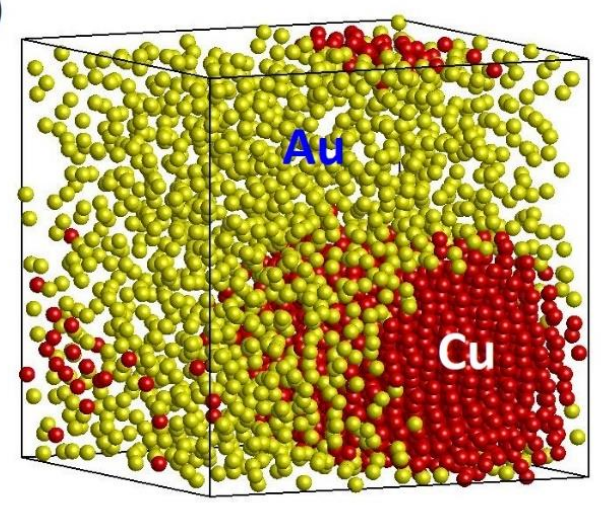

c)

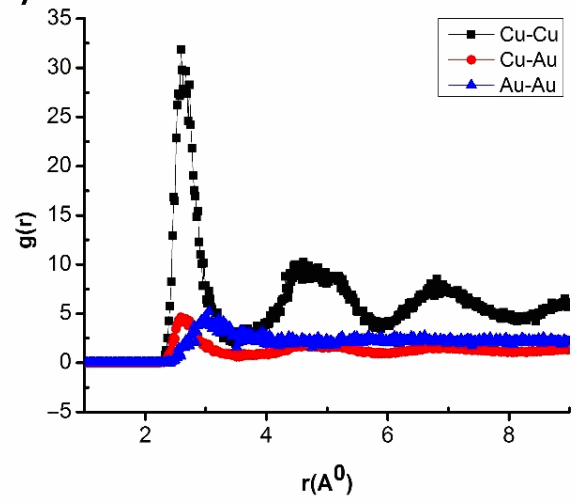

b)

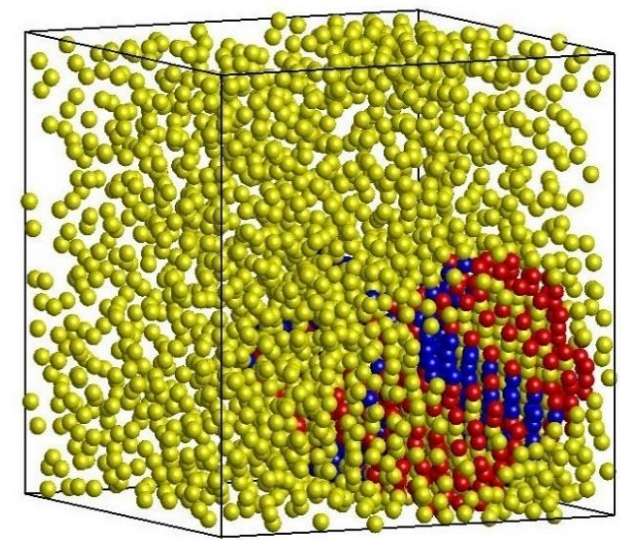

d)

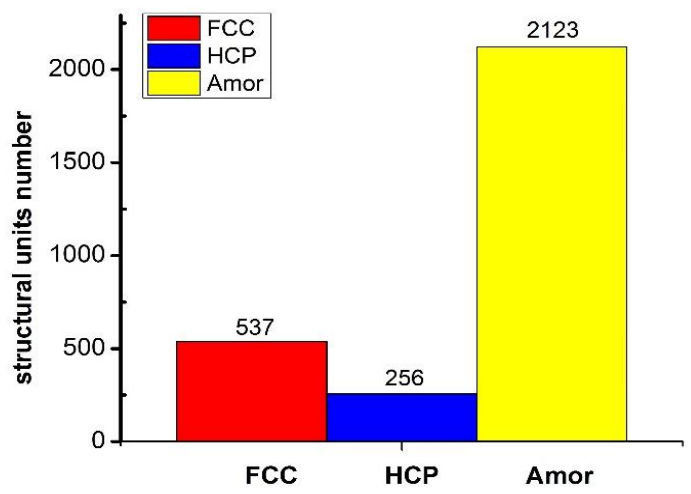

Figure 1. The shape (a), structural shape (b), radial distribution function (c), and number of structural units $(\mathrm{d})$ of $\mathrm{Cu}-\mathrm{Au}$ alloy at temperature $\mathrm{T}=300 \mathrm{~K}$, with a heating rate $4 \times 10^{12} \mathrm{~K} / \mathrm{s}$, and a time per heating step $\mathrm{h}=3.0 \mathrm{fs}$.

The result shows that $\mathrm{Cu}-\mathrm{Au}$ alloy has a cube shape, made of of two kinds of atoms: $\mathrm{Cu}$ in red and $\mathrm{Au}$ in yellow. After running the recovery statistics, raising the temperature on $\mathrm{T}=2000 \mathrm{~K}$, and then lowering the temperature to $\mathrm{T}=300 \mathrm{~K}$, the $\mathrm{Cu}$ and $\mathrm{Au}$ atoms shifted, leading to the formation of regions rich in $\mathrm{Cu}$ and Au atoms (Figure 1a). Similarly, with other characteristic values, such as structural shape, with FCC structure as red, HCP structure as blue, and Amor structure as yellow (Figure 1b), the radial distribution function (RDF) corresponds to the lengths (r) of links $\mathrm{Cu}-\mathrm{Cu}, \mathrm{Cu}-\mathrm{Au}$, and $\mathrm{Au}-\mathrm{Au}$ as $\mathrm{r}_{\mathrm{Cu}} \mathrm{Cu}=2.65 \AA$, $r_{\mathrm{Cu}-\mathrm{Au}}=2.66 \AA$, and $\mathrm{r}_{\mathrm{Au}-\mathrm{Au}}=3.05 \AA$, respectively; the height of $\mathrm{RDF}$ was $\mathrm{g}_{\mathrm{Cu}-\mathrm{Cu}}(\mathrm{r})=34.67$, $\mathrm{g}_{\mathrm{Cu}-\mathrm{Au}}(\mathrm{r})=5.22$, and $\mathrm{g}_{\mathrm{Au}-\mathrm{Au}}(\mathrm{r})=4.61$, the size $(\mathrm{l}), \mathrm{l}=8.36 \mathrm{~nm}, \mathrm{E}_{\text {tot }}=-194 \mathrm{eV}$ (Figure 1c), and structure units number was 537 FCC, 256 HCP, and 2123 Amor (Figure 1d). The cause of the formation of regions rich in $\mathrm{Cu}$ atoms and $\mathrm{Au}$ atoms (Figure 1a) was due to the influence of the atomic lattice constant size. With the $\mathrm{Au}$ atom having the lattice constant size $\mathrm{a}=4.080 \AA$, the value was larger than the atomic lattice constant of the $\mathrm{Cu}$ atom which was a $=3.615 \AA[92,93]$, leading to the Au atom not being able to fill the vacancy of the $\mathrm{Cu}$ atom. In addition, the electronic interaction force between $\mathrm{Au}-\mathrm{Au}$ atoms was larger than that of $\mathrm{Cu}-\mathrm{Cu}$ atoms. It was this that led to the formation of crystalline atoms with FCC structure, concentrated $\mathrm{HCP}$ occurs mainly with $\mathrm{Cu}$ atoms, and $\mathrm{Au}$ atoms are converted to an amorphous state (Figure $1 \mathrm{~b}, \mathrm{~d}$ ). The lengths link between $\mathrm{r}_{\mathrm{Cu}-\mathrm{Cu}}, \mathrm{r}_{\mathrm{Au}-\mathrm{Au}}$ atoms in $\mathrm{Cu}-\mathrm{Au}$ change greatly compared with the situation when there was doping with $\mathrm{Ni}$ (to make $\mathrm{NiCu}$ 
nano, NiCu bulk [68,71], and NiAu bulk [73]). To answer this question exactly, we study the influencing factors in the following section.

\subsection{Factors Affecting the Structure and Crystallization Process of $\mathrm{Cu}-\mathrm{Au}$ Alloy}

3.2.1. Time of Each Move Steps

The structural crystallization process of $\mathrm{Cu}-\mathrm{Au}$ alloy was carried out after increasing the time of each heating step. The obtained results are shown in Figure 2.
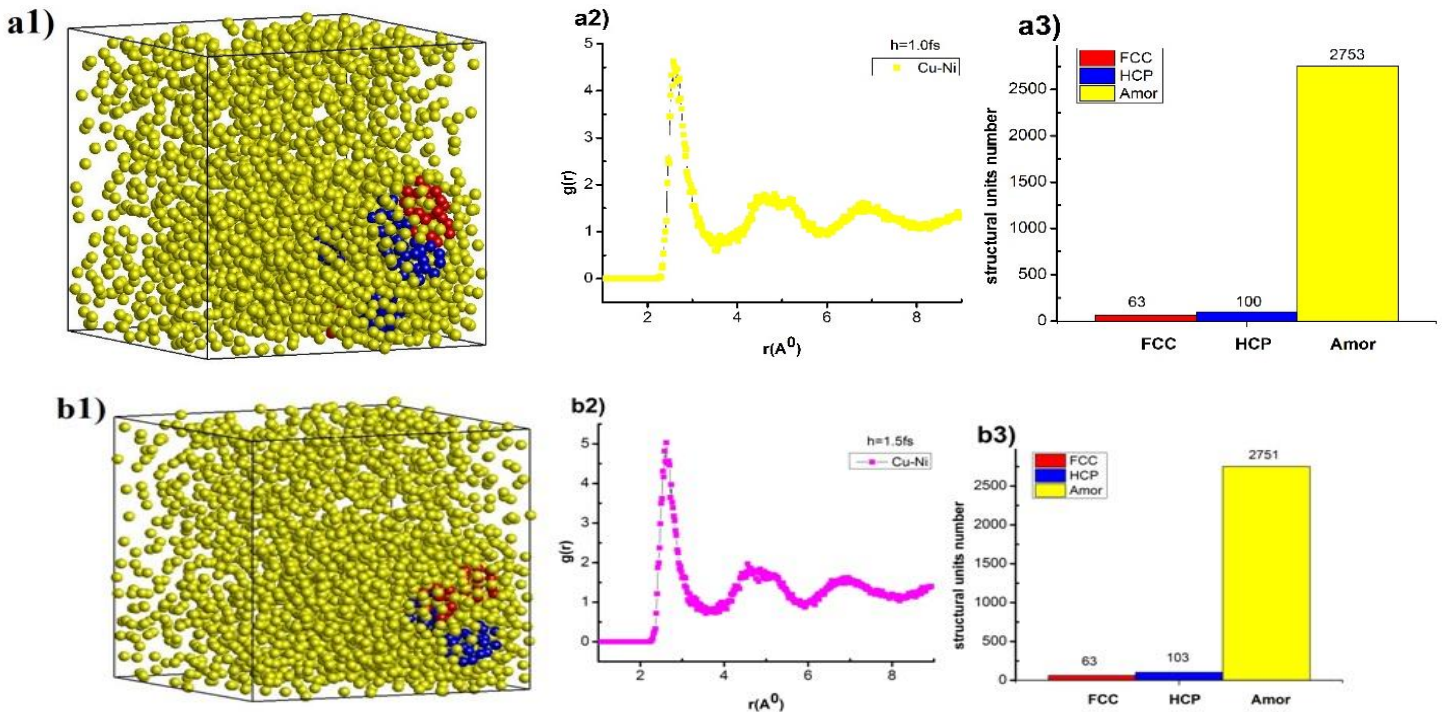

c1)
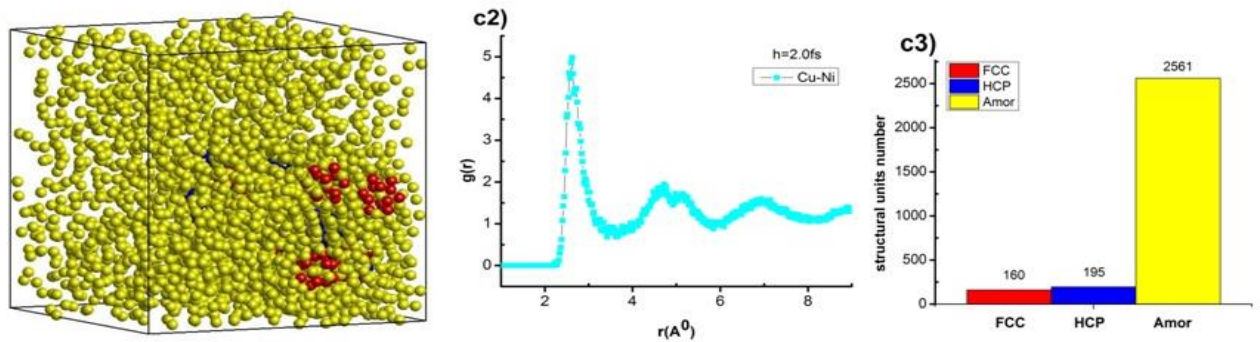

d1)
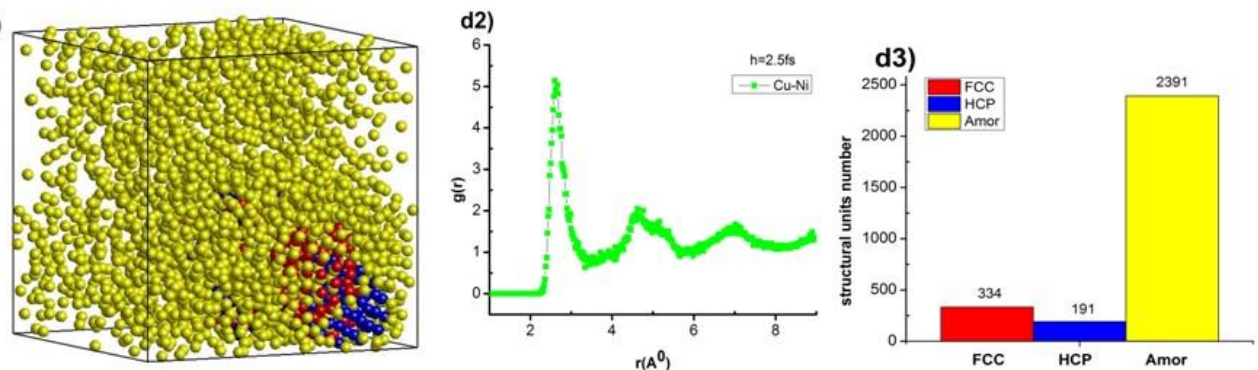

e1)
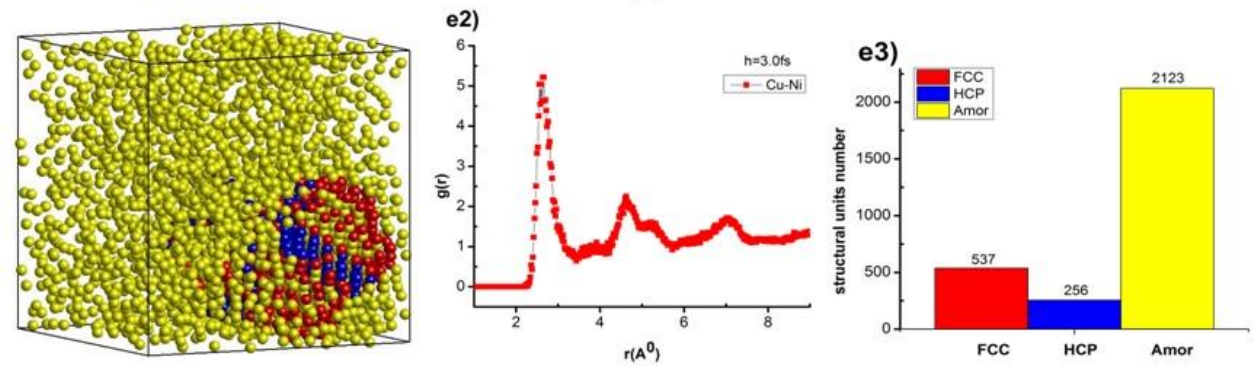

Figure 2. The structural shape (a1,b1,c1,d1,e1), radial distribution function $(\mathbf{a} 2, \mathbf{b} 2, \mathbf{c} 2, \mathbf{d} 2, \mathbf{e} 2)$, and number of structural units $(\mathbf{a} 3, \mathbf{b} 3, \mathbf{c} 3, \mathbf{d} 3, \mathbf{e} 3)$ of $\mathrm{Cu}-\mathrm{Au}$ alloy at temperature $\mathrm{T}=300 \mathrm{~K}$, heating rate $4 \times 10^{12} \mathrm{~K} / \mathrm{s}$ with a different time per heating step. 
The results show that, $\mathrm{Cu}-\mathrm{Au}$ alloy at temperature $(\mathrm{T}), \mathrm{T}=300 \mathrm{~K}$ with a calcination rate of $4 \times 10^{12} \mathrm{~K} / \mathrm{s}$, time each move step (h), $\mathrm{h}=1.0 \mathrm{fs}$ has the structure shape (Figure 2(a1)), the radial distribution function with $\mathrm{r}_{\mathrm{Cu}-\mathrm{Au}}=2.58 \AA$, the height of the RDF was $\mathrm{g}_{\mathrm{Cu}-\mathrm{Au}}(\mathrm{r})$ $=4.62$, size (l), $1=8.33 \mathrm{~nm}, \mathrm{E}_{\mathrm{tot}}=-193 \mathrm{eV}$ (Figure 2(a2)) and the structural units number was 63 FCC, 100 HCP, and 2753 Amor (Figure 2(a3)). When the time for each move step, $h$, was increased from $h=1.0$ fs to $1.5,2.0,2.5$, and $3.0 \mathrm{fs}$, the shape of the structure changes (Figure $2(\mathrm{a} 1, \mathrm{~b} 1, \mathrm{c} 1, \mathrm{~d} 1, \mathrm{e} 1))$, the length link of $\mathrm{Cu}-\mathrm{Au}$ increased from $\mathrm{r}_{\mathrm{Cu}-\mathrm{Au}}=2.58 \AA$ to $\mathrm{r}_{\mathrm{Cu}-\mathrm{Au}}=2.62,2.62,2.64$, and $2.66 \AA$, respectively, the height of the RDF increased from $\mathrm{g}_{\mathrm{Cu}-\mathrm{Au}}(\mathrm{r})=4.62$ to $\mathrm{g}_{\mathrm{Cu}-\mathrm{Au}}(\mathrm{r})=4.98,5.03,5.14$, and 5.22, respectively, the material size increased from $1=8.33 \mathrm{~nm}$ to $1=8.34,8.35,8.35$, and $8.36 \mathrm{~nm}$, respectively, total the energy of the system increased a little from $E_{t o t}=-193 \mathrm{eV}$ to $E_{t o t}=-193,-193,-193$, and $-194 \mathrm{eV}$, respectively (Figure $2(\mathrm{a} 2, \mathrm{~b} 2, \mathrm{c} 2, \mathrm{~d} 2, \mathrm{e} 2)$ ), and the structure units number changed: FCC increased from 63 FCC to 63, 160, 334, and 537 FCC; HCP increased from 100 HCP to 103, 195, 191, and $256 \mathrm{HCP}$; Amor decreased from 2752 Amor to 2751, 2561, 2391, and 2123 Amor (Figure 2(a3,b3,c3,d3,e3)). The reason for this phenomenon was that increasing the time of each heating step leads to increased in the displacement transition time of each $\mathrm{MD}$ step, giving the $\mathrm{Cu}$ and $\mathrm{Au}$ atoms bonding time. This shows that increasing $\mathrm{h}$ leads to increased crystallization, shown by increasing the length of $\mathrm{Cu}-\mathrm{Au}$ links, increasing the number of FCC and HCP structural units, and decreasing this number for Amor. These results show that there was a very great influence on the time of each heating step, but the increase in the time of each heating step leads to a strong increase in total simulation time. The time of each heating step is not workable in the current time of computer speed configuration, and we choose the time of each heating step as $h=3.0 \mathrm{fs}$ as a standard to study for other influence cases.

\subsubsection{Temperature}

Similarly, the effect of temperature on the structural and crystallization of the considered alloy is shown in Figure 3.

a)

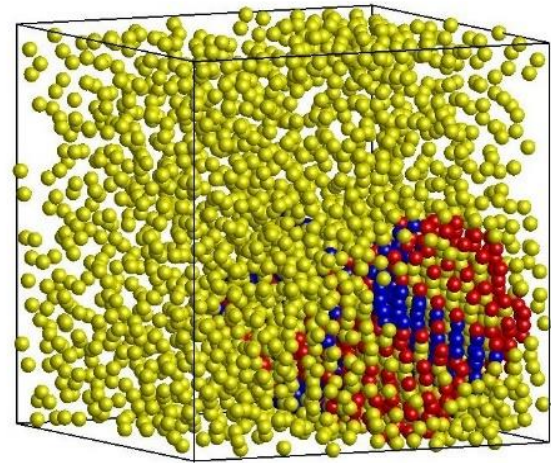

b)

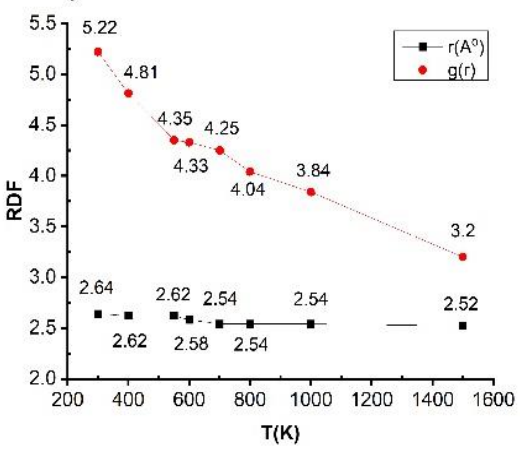

c)

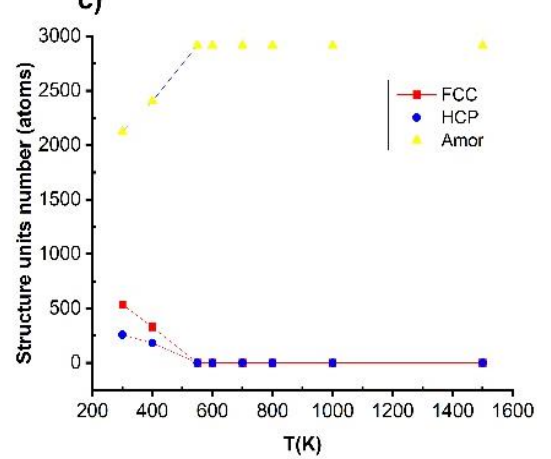

Figure 3. The structural shape (a), radial distribution function (b), and number of structural units (c) of $\mathrm{Cu}-\mathrm{Au}$ alloy at heating rate $4 \times 10^{12} \mathrm{~K} / \mathrm{s}$, time per heating step $\mathrm{h}=3.0 \mathrm{fs}$ with different values of temperature.

The result shows, with $\mathrm{Cu}-\mathrm{Au}$ alloy at temperature $(\mathrm{T}), \mathrm{T}=300 \mathrm{~K}$, heating rate of $4 \times 10^{12} \mathrm{~K} / \mathrm{s}$ and $\mathrm{h}=3.0 \mathrm{fs}$ has the length of link $(\mathrm{r})$ as $\mathrm{r}_{\mathrm{Cu}-\mathrm{Au}}=2.66 \AA$, the height of RDF was $\mathrm{g}_{\mathrm{Cu}-\mathrm{Au}}(\mathrm{r})=5.22$, size $(\mathrm{l}), 1=8.36 \mathrm{~nm}, \mathrm{E}_{\mathrm{tot}}=-194 \mathrm{eV}$ and structure units number was 537 FCC, 256 HCP, and 2123 Amor. Therefore, when the temperature (T) was increased from $\mathrm{T}=300 \mathrm{~K}$ to $\mathrm{T}=400,550,600,700,800,1000$, and $1500 \mathrm{~K}$, it was found that the structural shape of the material at $\mathrm{T}=300 \mathrm{~K}$ was such as that in Figure $3 \mathrm{a}$, and the radial distribution function links $\mathrm{Cu}-\mathrm{Au}$ has $\mathrm{r}_{\mathrm{Cu}-\mathrm{Au}}$ a change about $\mathrm{r}_{\mathrm{Cu}-\mathrm{Au}}=2.66 \AA$ to $\mathrm{r}_{\mathrm{Cu}-\mathrm{Au}}=2.62,2.60,2.58$, $2.54,2.54,2.66$, and $2.62 \AA$, respectively, the height of RDF decreased from $\mathrm{g}_{\mathrm{Cu}-\mathrm{Au}}(\mathrm{r})=5.22$ to $\mathrm{g}_{\mathrm{Cu}-\mathrm{Au}}(\mathrm{r})=4.81,4.33,4.33,4.25,3.84,3.82$, and 3.79 , respectively, the material size increased from $1=8.36 \mathrm{~nm}$ to $1=8.45,8.76,8.87,9.07,9.20,9.52$, and $10.01 \mathrm{~nm}$, respectively, 
the total energy of the system increased from $E_{t o t}=-194 \mathrm{eV}$ to $E_{t o t}=-190,-185,-182$, $-178,-176,-168$, and $-154 \mathrm{eV}$, respectively (Figure $3 \mathrm{~b}$ ), and the number of structural units changed: FCC decreased from 537 FCC to $339 \mathrm{FCC}$ at $\mathrm{T}$ from T $=300 \mathrm{~K}$ to $\mathrm{T}=400 \mathrm{~K}$; $\mathrm{HCP}$ decreased from $256 \mathrm{HCP}$ to $183 \mathrm{HCP}$ at T from $\mathrm{T}=300 \mathrm{~K}$ to $\mathrm{T}=400 \mathrm{~K}$; Amor increased from 2123 Amor to 2404 Amor at $\mathrm{T}$ from $\mathrm{T}=300 \mathrm{~K}$ to $\mathrm{T}=400 \mathrm{~K}$ (Figure 3c). Additionally, with $\mathrm{T}>550 \mathrm{~K}$, the $\mathrm{Cu}-\mathrm{Au}$ alloy turns to liquid state.

The obtained results show that when increasing the temperature, $\mathrm{T}$, leads to the size, 1 , the total energy of the Etot system increased, the bond length, r, does not change significantly, and the height of the radial distribution function, $g(r)$, decreased. The obtained results are completely consistent with previous publications with other alloys (as AlNi nano [67], NiCu nano and bulk [68,71], NiFe nano [69], and NiAu bulk [73]). Similarly, with the number of structural units FCC and HCP numbers decreased, Amor increased sharply, and there was a disappearance of the number of structural units at the temperature $\mathrm{T}=550 \mathrm{~K}$. The reason for this phenomenon was that size caused effects: when the temperature increased, the motion between atoms increased, and the interaction between atoms increased, combined with the phenomenon of thermal expansion leading to 1, Etot increased, $r$ has a negligible change, and $g(r)$ decreased. To confirm that, we studied the relationship between temperature and total energy of the system to determine the phase transition of the material. The results are shown in Figure 4.

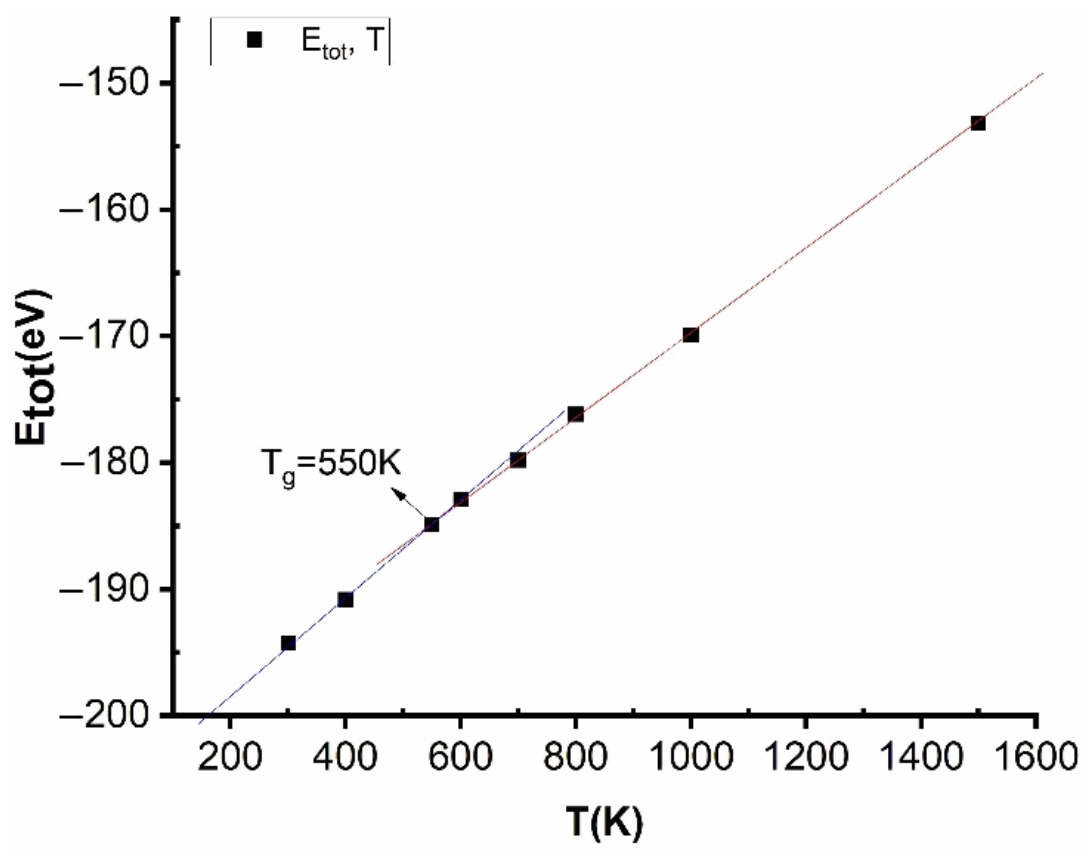

Figure 4. The phase transition of $\mathrm{Cu}-\mathrm{Au}$ alloy at a heating rate of $4 \times 10^{12} \mathrm{~K} / \mathrm{s}$, the time for each heating step was $h=3.0 \mathrm{fs}$ with different values of temperature.

The obtained results show that when $\mathrm{T}$ increased from $\mathrm{T}=300 \mathrm{~K}$ to $\mathrm{T}=400 \mathrm{~K}, 550 \mathrm{~K}$, $600 \mathrm{~K}, 700 \mathrm{~K}, 800 \mathrm{~K}, 1000 \mathrm{~K}$, and $1500 \mathrm{~K}$, the size, 1, has an insignificant change value in range from $1=8.36 \mathrm{~nm}$ to $1=10.01 \mathrm{~nm}$, and $E_{\text {tot }}$ increased from $E_{\text {tot }}=-194 \mathrm{eV}$ to Etot $=-190,-185,-182,-178,-176,-168$, and $-154 \mathrm{eV}$, respectively. In consequence, these results show that, with $\mathrm{T}<550 \mathrm{~K}, \mathrm{Cu}-\mathrm{Au}$ alloy exists in the crystalline state and for $\mathrm{T}>550 \mathrm{~K}$ was in a liquid state. Where, the structural shape of $\mathrm{Cu}-\mathrm{Au}$ alloy at $\mathrm{T}=550 \mathrm{~K}$ was amorphous. The intersection of the two lines of crystallization and the line in the liquid state is at a point, $\mathrm{T}=550 \mathrm{~K}$, which was called the crystallization point or the glass temperature $\left(\mathrm{T}_{\mathrm{g}}\right), \mathrm{T}_{\mathrm{g}}=\mathrm{T}=550 \mathrm{~K}$ (Figure 4 ). At the glass point, $\mathrm{T}_{\mathrm{g}}=550 \mathrm{~K}$ has the total energy of the system $E_{\text {tot }}=-185 \mathrm{eV}$, results consistent with the value of crystallization temperature of $\mathrm{Cu}-\mathrm{Au} \mathrm{T}=543 \mathrm{~K}[48]$ and in the range from $\mathrm{T}=543 \mathrm{~K}$ to $\mathrm{T}=683 \mathrm{~K}[60,61]$. 
The obtained results show that the choice of embedded interaction potential Sutton-Chen (SC) is completely appropriate.

\subsubsection{Heat Annealing Time}

The effect of annealing time on the structure and crystallization process of $\mathrm{Cu}-\mathrm{Au}$ alloy is shown in Figure 5.

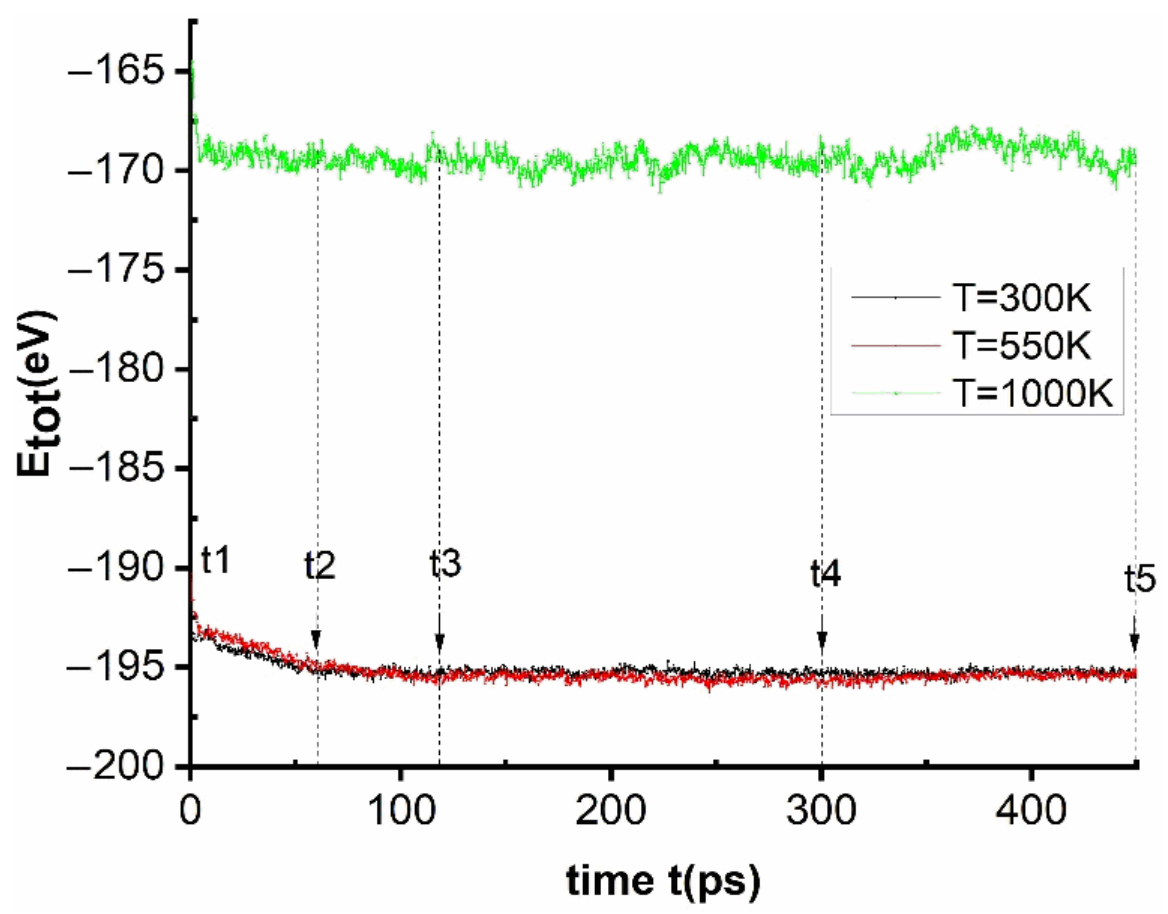

Figure 5. The relationship between the annealing time and the total energy of the system at temperatures $\mathrm{T}=300,400,550,600$, and $1000 \mathrm{~K}$.

The obtained results show that, at the initial time without annealing, $\mathrm{t} 1=0 \mathrm{ps}$, the energy of the material at temperature $\mathrm{T}=300,400,550,600$, and $1000 \mathrm{~K}$ has the corresponding energy value $\mathrm{E}_{\mathrm{tot}}=-198,-196,-192,-190$, and $-182 \mathrm{eV}$, respectively. When the annealing time was increased from $\mathrm{t} 1=0$ ps to $\mathrm{t} 2=60 \mathrm{ps}\left(2 \times 10^{4} \mathrm{MD}\right.$ steps $), \mathrm{t} 3=120$ ps $\left(4 \times 10^{4} \mathrm{MD}\right.$ steps $), \mathrm{t} 4=300 \mathrm{ps}\left(10 \times 10^{4} \mathrm{MD}\right.$ steps $)$, and $\mathrm{t} 5=450 \mathrm{ps}\left(15 \times 10^{4} \mathrm{MD}\right.$ steps $)$, the total energy of the material in the corresponding temperatures have variable values (Figure 5). When the temperatures $\mathrm{T}=400,600$, and $1000 \mathrm{~K}$, the values change are not significant. When $\mathrm{T}=300$ and $550 \mathrm{~K}$, the energy of the material decreased rapidly from the point $\mathrm{t} 1=0 \mathrm{ps}$ to $\mathrm{t} 2=60 \mathrm{ps}$, and after that gradually slows down from $\mathrm{t} 2=60 \mathrm{ps}$ to $\mathrm{t} 3=120$ ps, whereas from $\mathrm{t} 3$ to $\mathrm{t} 4$, $\mathrm{t} 5$ was almost constant. It follows that the material has a strong crystallization process at the temperature $\mathrm{T}=550 \mathrm{~K}$-namely, this was the phase transition of the material's crystallization with $\mathrm{T}_{\mathrm{g}}=550 \mathrm{~K}$. At temperatures $\mathrm{T}=300$ and $400 \mathrm{~K}$, the crystallization process occurs slowly; finally, at T > $600 \mathrm{~K}$, crystallization does not occur because this was the region where the material has changed to a liquid state. To confirm that, we examined the structure and crystallization process at each specific temperature and the results are shown in Figure 6. 
a1)

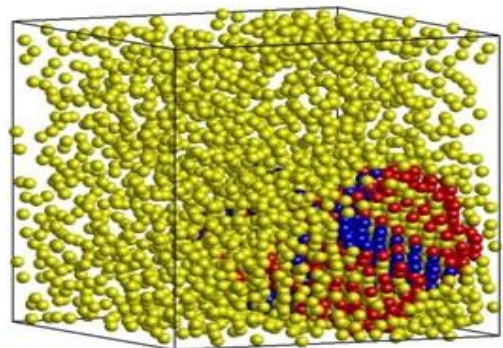

a2)

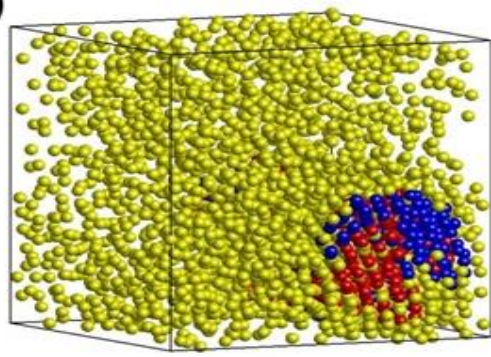

a3)

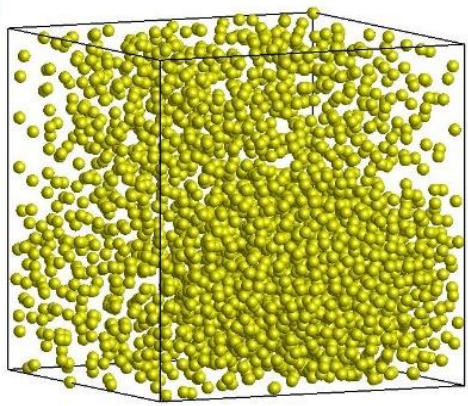

a4)

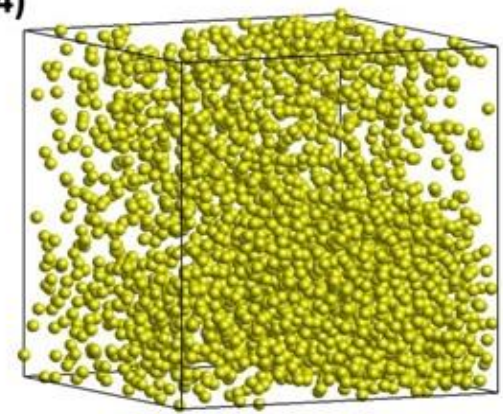

a5)

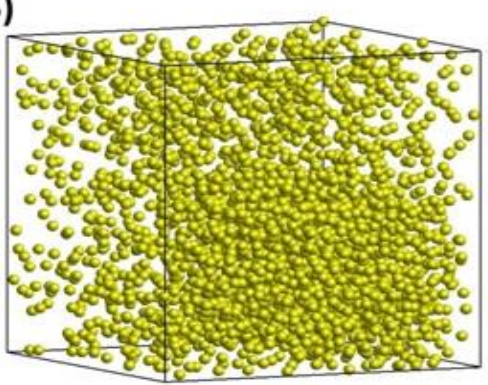

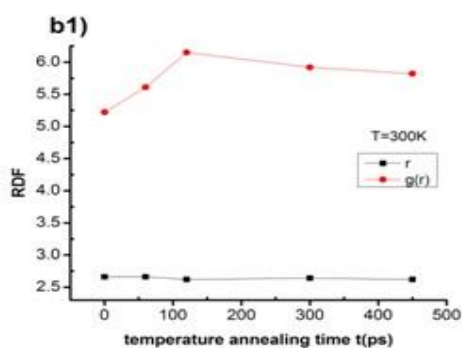

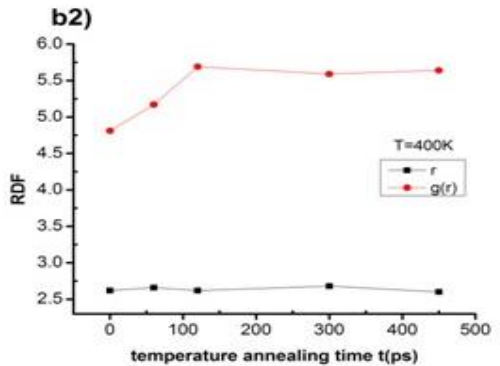

b3)
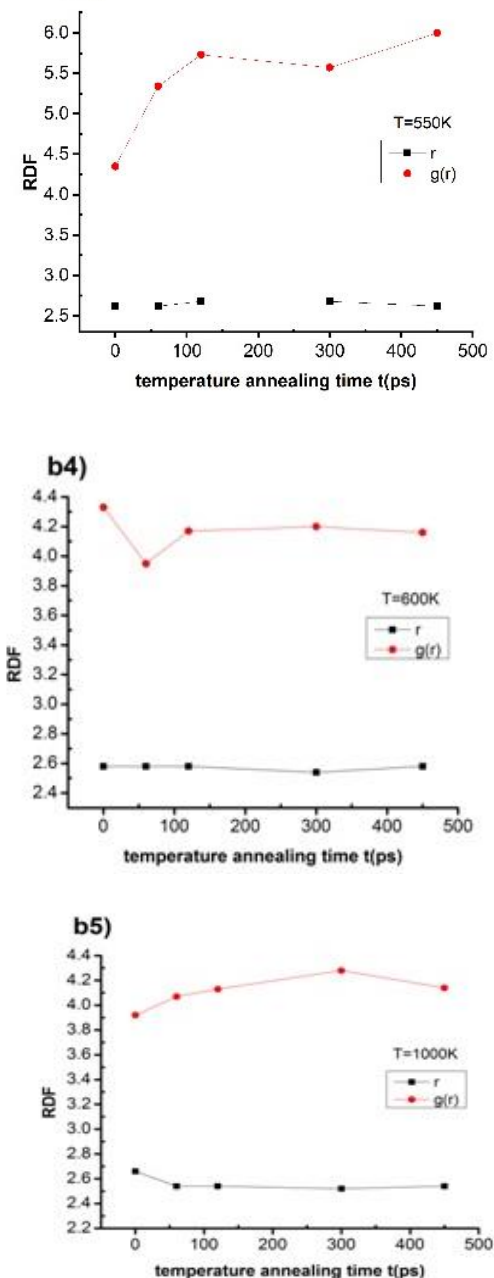
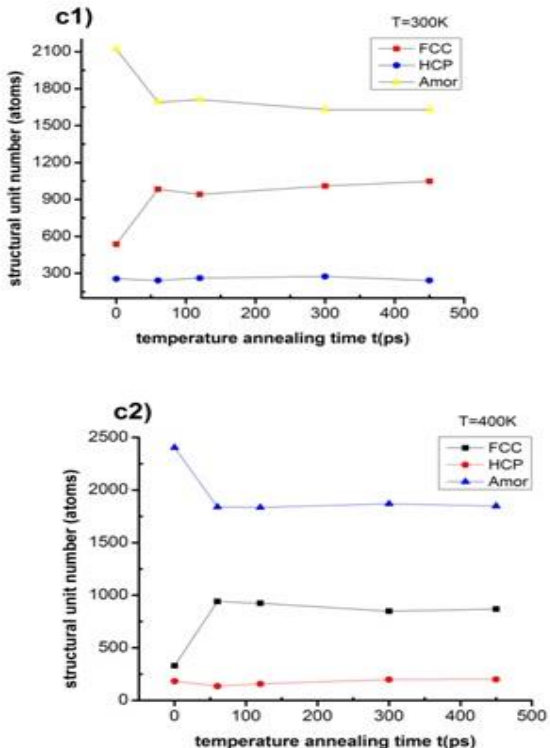

c3)
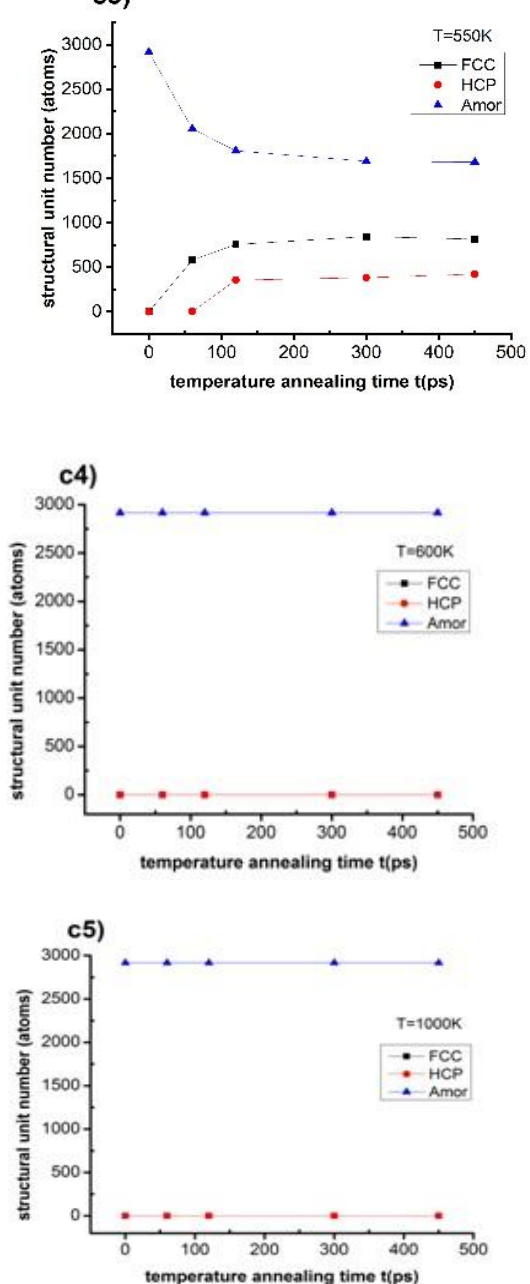

Figure 6. The structural shape (a1,a2,a3,a4, a5), radial distribution function $(\mathbf{b} 1, \mathbf{b} 2, \mathbf{b} 3, \mathbf{b} 4, \mathbf{b} 5)$, and number of structural units $(\mathbf{c 1}, \mathbf{c 2}, \mathbf{c 3}, \mathbf{c 4}, \mathbf{c 5})$ of $\mathrm{Cu}-\mathrm{Au}$ alloy at heating rate $4 \times 10^{12} \mathrm{~K} / \mathrm{s}$, time per heating step $\mathrm{h}=3.0 \mathrm{fs}$, and the values of temperature $\mathrm{T}=300,400,550,600$, and $1000 \mathrm{~K}$. 
The results show that $\mathrm{Cu}-\mathrm{Au}$ alloy at temperature $(\mathrm{T}) \mathrm{T}=300 \mathrm{~K}$ with a calcination rate $4 \times 10^{12} \mathrm{~K} / \mathrm{s}$, time per heating step $(\mathrm{h}), \mathrm{h}=3.0 \mathrm{fs}$ at heat annealing time $(\mathrm{t}), \mathrm{t} 1=0 \mathrm{ps}$ has the structure shown in Figure 6(a1), the radial distribution function with $\mathrm{r}_{\mathrm{Cu}-\mathrm{Au}}=2.66 \AA$, the height of the RDF was $\mathrm{g}_{\mathrm{Cu}-\mathrm{Au}}(\mathrm{r})=5.22$, size $(\mathrm{l}), 1=8.36 \mathrm{~nm}, \mathrm{E}_{\mathrm{tot}}=-198 \mathrm{eV}$, and the number of structural units was 537 FCC, 256 HCP, and 2123 Amor. When increasing the heat annealing time $t$ from $t 1=0$ ps to $t 2=60 \mathrm{ps}, \mathrm{t} 3=120 \mathrm{ps}, \mathrm{t} 4=300 \mathrm{ps}$, and $\mathrm{t} 5=450 \mathrm{ps}$, the length link of $\mathrm{Cu}$-Au decreased from $\mathrm{r}_{\mathrm{Cu}-\mathrm{Au}}=2.66 \AA$ to $\mathrm{r}_{\mathrm{Cu}-\mathrm{Au}}=2.66,2.62,2.64$, and $2.66 \AA$, respectively, the height of the RDF increased from $\mathrm{g}_{\mathrm{Cu}-\mathrm{Au}}(\mathrm{r})=5.22$ to $\mathrm{g}_{\mathrm{Cu}-\mathrm{Au}}(\mathrm{r})=5.61$, $6.15,5.92$, and 5.82, respectively, the material size decreased from $1=8.36 \mathrm{~nm}$ to $1=8.33$, $8.3,8.33$, and $8.32 \mathrm{~nm}$, respectively, the total the energy of the system change decreased from $\mathrm{E}_{\mathrm{tot}}=-198 \mathrm{eV}$ to $\mathrm{E}_{\mathrm{tot}}=-195,-195,-195$, and $-195 \mathrm{eV}$, respectively, and the number of structural units changed: FCC increased from 537 FCC to 984, 942, 1010, and 1048 FCC, respectively, and HCP change increased from 256 HCP to 243, 262, 275, and 242 HCP, respectively, whereas for Amor it decreased from 2123 Amor to 1689, 1712, 1631, and 1631 Amor, respectively (Figure 6(b1,c1)). Similarly, with $\mathrm{T}=400 \mathrm{~K}$, we considered that the alloy has the structure as in Figure 6(a2), and the length link of $\mathrm{Cu}-\mathrm{Au}$ change increased from $\mathrm{r}_{\mathrm{Cu}-\mathrm{Au}}=2.62 \AA$ to $\mathrm{r}_{\mathrm{Cu}-\mathrm{Au}}=2.6 \AA$, the height of the RDF increased from $\mathrm{g}_{\mathrm{Cu}-\mathrm{Au}}(\mathrm{r})=4.81$ to $\mathrm{g}_{\mathrm{Cu}-\mathrm{Au}}(\mathrm{r})=5.64$, the material size remained constant with $1=8.45 \mathrm{~nm}$, the total the energy of the system decreased from $E_{\text {tot }}=-196 \mathrm{eV}$ to $E_{\text {tot }}=-191 \mathrm{eV}$, and the number of structural units changed: FCC increased from 329 FCC to 868 FCC, HCP increased from $183 \mathrm{HCP}$ to $200 \mathrm{HCP}$, and Amor decreased from 2404 Amor to 1848Amor (Figure $6(\mathrm{~b} 2, \mathrm{c} 2))$. For $\mathrm{T}=550 \mathrm{~K}$, considering that the alloy has the structure shown in Figure 6(a3), the length link of $\mathrm{Cu}-\mathrm{Au}$ decreased from $\mathrm{r}_{\mathrm{Cu}-\mathrm{Au}}=2.62 \AA$ to $\mathrm{r}_{\mathrm{Cu}-\mathrm{Au}}=2.62 \AA$, the height of the RDF change increased from $\mathrm{g}_{\mathrm{Cu}-\mathrm{Au}}(\mathrm{r})=4.35$ to $\mathrm{g}_{\mathrm{Cu}-\mathrm{Au}}(\mathrm{r})=6.0$, the material size remained almost constant from $1=8.76 \mathrm{~nm}$ to $8.36 \mathrm{~nm}$, total the energy of the system decreased from $\mathrm{E}_{\mathrm{tot}}=-192 \mathrm{eV}$ to $\mathrm{E}_{\mathrm{tot}}=-195 \mathrm{eV}$ and the number of structural units changed: FCC increased from 0 FCC to 814 FCC, HCP increased from $0 \mathrm{HCP}$ to $422 \mathrm{HCP}$, and Amor decreased from 2916 Amor to 1680 Amor (Figure 6(b3,c3)). In the case of $\mathrm{T}=600$ and $1000 \mathrm{~K}$, then the alloy has the structure as in Figure 6(a4,a5), the length of the link of $\mathrm{Cu}-\mathrm{Au}$ does not change with $\mathrm{r}_{\mathrm{Cu}-\mathrm{Au}}=2.58 \AA$, the height of the RDF change decreased from $\mathrm{g}_{\mathrm{Cu}-\mathrm{Au}}(\mathrm{r})=4.33$ to $\mathrm{g}_{\mathrm{Cu}-\mathrm{Au}}(\mathrm{r})=4.16$, the material size remained constant with $1=8.87 \mathrm{~nm}$, total the energy of the system decreased from $E_{\text {tot }}=-190 \mathrm{eV}$ to $E_{\text {tot }}=-182 \mathrm{eV}$, and the number of structure units did not change with 0 FCC, 0 HCP, and 2916 Amor (Figure 6(b4,c4)). With $\mathrm{T}=600 \mathrm{~K}$ and with $\mathrm{T}=1000 \mathrm{~K}$ then, the length of the link of $\mathrm{Cu}-\mathrm{Au}$ decreased from $\mathrm{r}_{\mathrm{Cu}-\mathrm{Au}}=2.66 \AA$ to $\mathrm{r}_{\mathrm{Cu}-\mathrm{Au}}=2.54 \AA$, the height of the RDF increased from $\mathrm{g}_{\mathrm{Cu}-\mathrm{Au}}(\mathrm{r})=3.92$ to $\mathrm{g}_{\mathrm{Cu}-\mathrm{Au}}(\mathrm{r})=4.14$, the material size remained constant with $1=9.52 \mathrm{~nm}$, total the energy of the system decreased from $\mathrm{E}_{\mathrm{tot}}=-182 \mathrm{eV}$ to $\mathrm{E}_{\mathrm{tot}}=-169 \mathrm{eV}$, and the number of structure units no changed with 0 FCC, 0 HCP, and 2916 Amor (Figure 6(b5,c5)). The obtained results show that the above predictions are completely consistent with the obtained results, with the cause of the phase transition from the crystalline state to the liquid state, by the size effect and phase transition of the material, is phase transition type 1. The obtained results of $\mathrm{Cu}-\mathrm{Au}$ alloy can serve as a basis for future experimental studies.

\section{Conclusions}

After studying the influence of time per heating step, temperature, and annealing time on the structure and crystallization process of $\mathrm{Cu}-\mathrm{Au}$ alloy, we obtained the following results: $\mathrm{Cu}-\mathrm{Au}$ alloy exists by two types of $\mathrm{Cu}$ and $\mathrm{Au}$ atoms, and these atoms form to two rich regions of $\mathrm{Cu}$ atoms and $\mathrm{Au}$ atoms. When the time of each move step increased, the length of the link of $\mathrm{Cu}-\mathrm{Au}$ increased from $\mathrm{r}_{\mathrm{Cu}-\mathrm{Au}}=2.58 \AA$ to $\mathrm{r}_{\mathrm{Cu}-\mathrm{Au}}=2.66 \AA$, the height of the RDF increased from $\mathrm{g}_{\mathrm{Cu}-\mathrm{Au}}(\mathrm{r})=4.62$ to $\mathrm{g}_{\mathrm{Cu}-\mathrm{Au}}(\mathrm{r})=5.22$, the material size increased from $1=8.33 \mathrm{~nm}$ to $1=8.36 \mathrm{~nm}$, and the total the energy of the system increased a little from $\mathrm{E}_{\mathrm{tot}}=-193 \mathrm{eV}$ to $\mathrm{E}_{\mathrm{tot}}=-194 \mathrm{eV}$. This shows that the timing of each move step determines the crystallization process of the material. Similarly, increasing the temperature leads to an 1 increase, an $E_{\text {tot }}$ increase, a decrease in the number of structural units of FCC and HCP, 
and Amor increased, which led to a decrease in the crystallization process. In addition, the glass temperature $\left(\mathrm{T}_{\mathrm{g}}\right)$ of the material was $\mathrm{T}_{\mathrm{g}}=550 \mathrm{~K}$. When increasing the annealing time at $\mathrm{T}=300,400,550,600$, and $1000 \mathrm{~K}$, we showed that, with materials at $\mathrm{T}=300$, and $400 \mathrm{~K}$ for slow crystallization, $\mathrm{T}=\mathrm{T}_{\mathrm{g}}=550 \mathrm{~K}$ for fast crystallization, and $\mathrm{T}=600$ and $1000 \mathrm{~K}$, no over-crystallization occurs. The obtained results of $\mathrm{Cu}-\mathrm{Au}$ alloy are very helpful and can serve as a basis for future experimental studies, in particular, the exact value of the glass temperature was $\mathrm{Tg}=550 \mathrm{~K}$ and during the phase transition, link length $(\mathrm{r})$, total energy (Etot), size (1), number of FCC, HCP, and Amor structural units will have a significant change.

Author Contributions: Conceptualization, D.N.T.; method, D.N.T.; validation, D.N.T.; investigation, D.N.T.; writing - original draft preparation, T.T.Q., D.N.T., V.C.L. and Ş.T.; writing-review and editing, D.N.T., V.C.L. and S..Tु.; data curation, V.C.L. All authors have read and agreed to the published version of the manuscript.

Funding: This research was funded by the University of Transport Technology (UTT), Viet Nam under grant number: ĐTТĐ2021-10.

Data Availability Statement: The data that supports the findings of this study are available from the corresponding author upon reasonable request.

Conflicts of Interest: The authors declare no conflict of interest. The funders had no role in the design of the study; in the collection, analyses, or interpretation of the data; in the writing of the manuscript, or in the decision to publish the results.

\section{References}

1. Satoh, A. Introduction to Practice of Molecular Simulation; Elsevier Inc.: Burlington, MA, USA, 2011.

2. Mostowski, J.; Trippenbach, M.; Van, C.L. Phase Space Approach to Two-electron Atom Ionisation. In Proceedings of the Fourth International Conference on Multiphoton Processes, Boulder, CO, USA, 13-17 July 1987.

3. Perla, B.; Jorge, M.S. Molecular Dynamics: From Classical to Quantum Methods; Elsevier: Amsterdam, The Netherlands, 1999.

4. Van, C.L.; Goldstein, P. Concise Course in Nonlinear Partial Diferential Equations; Publishing House of the University of Zielona Góra: Zielona Góra, Poland, 2008.

5. Basile, A.; Parmaliana, A.; Tosti, S.; Iulianelli, A.; Gallucci, F.; Espro, C.; Spooren, J. Hydrogen production by methanol steam reforming carried out in membrane reactor on $\mathrm{Cu} / \mathrm{Zn} / \mathrm{Mg}$-based catalyst. Catal. Today 2008, 137, 17-22. [CrossRef]

6. Yoo, W.; Li, C. Copper-catalyzed oxidative esterification of alcohols with aldehydes activated by Lewis acids. Tetrahedron Lett. 2007, 48, 1033-1035. [CrossRef]

7. Fujitani, T.; Saito, M.; Kanai, Y.; Kakumoto, T.; Watanabe, T.; Nakamura, J.; Uchijima, T. The role of metal oxides in promoting a copper catalyst for methanol synthesis. Catal. Lett. 1994, 25, 271-276. [CrossRef]

8. Li, X.; Cai, W.; An, J.; Kim, S.; Nah, J.; Yang, D.; Piner, R.; Velamakanni, A.; Jung, I.; Tutuc, E.; et al. Large-area synthesis of high-quality and uniform graphene films on copper foils. Science 2009, 324, 1312-1314. [CrossRef]

9. Hutchings, G.J.; Brust, M.; Schmidbaur, H. Gold-an introductory perspective. Chem. Soc. Rev. 2008, 37, 1759-1765. [CrossRef]

10. Ye, S.; Brown, A.P.; Stammers, A.C.; Thomson, N.H.; Wen, J.; Roach, L.; Bushby, R.J.; Coletta, P.L.; Critchley, K.; Connell, S.D. Sub-nanometer thick gold nanosheets as highly efficient catalysts. Adv. Sci. 2019, 1900911. [CrossRef]

11. Valden, M.; Lai, X.; Goodman, D.W. Onset of catalytic activity of gold clusters on titania with the appearance of nonmetallic properties. Science 1998, 281, 1647-1650. [CrossRef]

12. Haruta, M. Size- and support-dependency in the catalysis of gold Catal. Today 1997, 36, 153-166. [CrossRef]

13. Ferrando, R.; Jellinek, J.; Johnson, R.L. Application of Copper-Gold Alloys in Catalysis: Current Status and Future Perspectives. Chem. Rev. 2008, 108, 846-890.

14. Iwai, H.; Umeki, T.; Yokomatsu, M.; Egawa, C. Methanol partial oxidation on Cu-Zn thin films grown on Ni(1 0 0) surface. Surf. Sci. 2008, 602, 2541-2546. [CrossRef]

15. Pérez-Hernandeza, R.; Mondragon Galiciaa, G.; Mendoza Anayaa, D.; Palaciosa, J.; Angeles-Chavezb, C.; Arenas-Alatorrec, J. Synthesis and characterization of bimetallic $\mathrm{Cu}-\mathrm{Ni} / \mathrm{ZrO}_{2}$ nanocatalysts: $\mathrm{H}_{2}$ production by oxidative steam reforming of methanol. Int. J. Hydrogen Energy 2008, 33, 4569-4576. [CrossRef]

16. Bond, G.C.; Louis, C.; Thompson, D.T. Catalysis by Gold; World Scientific: Singapore, 2006.

17. Corma, A.; Garcia, H. Supported gold nanoparticles as catalysts for organic reactions. Chem. Soc. Rev. 2008, 37, 2096-2126. [CrossRef] [PubMed]

18. Nemoshkalenko, V.V.; Chuistov, K.V.; Aleshin, V.G.; Senkevich, A.I. Changes in energy structure of Cu3Au and CuAu3 alloys studied by the method of X-ray photoelectron spectroscopy. J. Electron Spectrosc. Relat. Phenom. 1976, 9, 169-173. [CrossRef]

19. Daw, M.S.; Baskes, M.I. Model of metallic cohesion: The embedded-atom method. Phys. Rev. B 1989, 39, 7441. [CrossRef] [PubMed] 
20. Finnis, M.W.; Sinclair, J.E. A simple empirical N-body potential for transition metals. Phil. Mag. A 1984, 50, 45-55. [CrossRef]

21. Murray, S.-D.; Stephen, M.-F.; Michael, I.-B. The embedded-atom method: A review of theory and applications. Mater. Sci. Rep. 1993, 9, 251-310.

22. Ercolessi, F.; Parrinello, M.; Tosatti, E. Melting and equilibrium shape of icosahedral gold nanoparticles. Phil. Mag. A 1988, 58, 213. [CrossRef]

23. Alavi, S. Molecular Simulations: Fundamentals and Practice; Wiley-VCH Verlag GmbH: Weinheim, Germany, 2020.

24. Rapaport, D.C. The Art of Molecular Dynamics Simulation; Cambridge University Press: Cambridge, UK, 1995.

25. Frenkel, D.; Smit, B. Understanding Molecular Simulation; Academic: San Diego, CA, USA, 1996.

26. Dung, N.-T.; Cuong, N.-C.; Hung, T.-V. Molecular dynamics study of microscopic structures, phase transitions and dynamic crystallization in Ni nanoparticles. RSC Adv. 2017, 7, 25406-25413.

27. Li, Q.; Peng, X.; Peng, T.; Tang, Q.; Zhang, X.; Huang, C. Molecular dynamics simulation of Cu/Au thin films under temperature gradient. Appl. Surf. Sci. 2015, 357, 1823-1829. [CrossRef]

28. Potter, A.A.; Hoyt, J.J. A molecular dynamics simulation study of the crystal-melt interfacial free energy and its anisotropy in the $\mathrm{Cu}-\mathrm{Ag}-\mathrm{Au}$ ternary system. J. Cryst. Growth 2011, 327, 227-232. [CrossRef]

29. Chepkasov, I.V.; Gafner, Y.Y.; Vysotin, M.A.; Redel, L.V. A study of melting of various types of Pt-Pd nanoparticles. Phys. Solid State 2017, 59, 2076-2081. [CrossRef]

30. Baidyshev, V.S.; Gafner, Y.Y.; Gafner, S.L.; Redel, L.V. Thermal stability of Pt nanoclusters interacting to carbon sublattice. Phys. Solid State 2017, 59, 2512-2518. [CrossRef]

31. Artrith, N.; Kolpak, A.M. Grand canonical molecular dynamics simulations of $\mathrm{Cu}$-Au nanoalloys in thermal equilibrium using reactive ANN potentials. Comput. Mater. Sci. 2015, 110, 20-28. [CrossRef]

32. The Materials Project. Materials Data on CuAu by Materials Project; U.S. Department of Energy Office of Scientific and Technical Information: Berkeley, CA, USA, 2020. [CrossRef]

33. Georg, Z.; Michele, R.; Clemens, M.; Daniel, S.; Cesare, F.; Jani, K. CuAu, a hexagonal two-dimensional metal, 2 D. Mater 2020, 7, 045017.

34. Çagın, T.; Dereli, G.; Uludogan, M.; Tomak, M. Thermal and mechanical properties of some fcc transition metals. Phys. Rev. $B$ 1999, 59, 3468-3473. [CrossRef]

35. Jacek, D. Quantum classical calculations of the nanomechanical properties of metals. Task Q. 2009, 13, $207-310$.

36. Ozdemir Kart, S.; Tomak, M.; Uludogan, M.; Cagın, T.J. Liquid properties of Pd-Ni alloys. Non-Cryst. Solids 2004, 337, 101-108. [CrossRef]

37. Kart, S.O.; Tomak, M.; Cagın, T. Phonon dispersions and elastic constants of disordered Pd-Ni alloys. Phys. B 2005, $355382-355391$. [CrossRef]

38. Kart, H.H.; Uludogan, M.; Cagın, T.; Tomak, M.J. Simulation of crystallization and glass formation of binary Pd-Ag metal alloys. Non-Cryst. Solids 2004, 342, 6-11. [CrossRef]

39. Kart, H.-H.; Tomak, M.; Çağin, T. Molecular Dynamics Study of Thermal Properties of Intermetallic Alloys. Turk. J. Phys. 2006, 30, 311-317.

40. Kart, H.H.; Tomak, M.; Uludogan, M.; Cagın, T. Thermodynamical and mechanical properties of Pd-Ag alloys. Comput. Mater. Sci. 2004, 32, 107-117. [CrossRef]

41. Hashmi, A.S.K.; Hutchings, G.J. Gold-Katalyse. Angew. Chem. 2006, 118, 8064-8105. [CrossRef]

42. Liu, X.; Wang, A.; Li, L.; Zhang, T.; Mou, C.Y.; Lee, J.F. Structural changes of Au-Cu bimetallic catalysts in CO oxidation: In situ XRD, EPR, XANES, and FT-IR characterizations. J. Catal. 2011, 278, 288-296. [CrossRef]

43. Bazulev, A.N.; Samsonov, A.N.; Sdobnyakov, N.Y. Thermodynamic perturbation theory calculations of interphase tension in small objects. Russ. J. Phys. Chem. A 2002, 76, 1872-1876.

44. Chen, S.; Jenkins, S.V.; Tao, J.; Zhu, Y.; Chen, J. Anisotropic Seeded Growth of Cu-M (M = Au, Pt, or Pd) Bimetallic Nanorods with Tunable Optical and Catalytic Properties. J. Phys. Chem. C 2013, 117, 8924-8932. [CrossRef]

45. Williams, P.L.; Mishin, Y.; Hamilton, J.C. An embedded-atom potential for the Cu-Ag system. Model. Simul. Mater. Sci. Eng. 2006, 14, 817-833. [CrossRef]

46. Whang, S.-H.; Pope, D.-P.; Liu, C.-T. High Temperature Aluminides and Intermetallics. In Proceedings of the Second International ASM Conference, San Diego, CA, USA, 16-19 September 1991; Volume 7.

47. Arunachalam, V.S.; Cahn, R.W. Order-hardening in CuAu. J. Matter. Sci. 1967, 2, 160-170. [CrossRef]

48. Volkov, A.Y. Structure and Mechanical Properties of CuAu and CuAuPd Ordered Alloys. Gold Bull. 2004, 37, 208-215. [CrossRef]

49. Hidalgo-Alvarez, R. Structure and Functional Properties of Colloidal Systems; CRC Press: Boca Raton, FL, USA, 2009; pp. 180-184.

50. Riccardo, F. Structure and Properties of Nanoalloys; Elsevier: Amsterdam, The Netherlands, 2016.

51. Mikhail, S.; Alexander, Y.; Nikita, S. Structural transformation in nanowires CuAu I with superstructure of L10 of tetragonal symmetry at uni-axial tension deformation. Eng. Mater. 2014, 592-593, 51-54.

52. Tsaregorodtsev, A.I.; Gorlov, N.V.; Dem'yanov, B.F.; Starostenkov, M.D. Atomic structure of antiphase boundaries and its impact on the lattice near the dislocations in ordered alloys with superstructure L12. Phys. Met. Metallogr. 1984, 58, 336-343.

53. Dmitriev, S.V.; Kozlov, E.V.; Lomskih, N.V.; Starostenkov, M.D. The kinetics of disorder in the two-dimensional model of the alloy. Russ. Phys. J. 1997, 40, 285-286. [CrossRef]

54. Papageorgiou, D.G.; Lagaris, I.E.; Papanicolaou, N.I.; Petsos, G.; Polatoglou, H.M. Merlin a versatile optimization environment applied to the design of metallic alloys and intermetallic compounds. Comput. Mater. Sci. 2003, 28, 125-133. [CrossRef] 
55. Wang, L.; Zhang, Y.; Yang, H.; Chen, Y. Structural simulation of super-cooled liquid Au-Cu, Au-Ag alloys. Phys. Lett. A 2003, 317, 489-494. [CrossRef]

56. Han, X.J.; Chen, M.; Guo, Z.Y.J. Thermophysical properties of undercooled liquid Au-Cu alloys from molecular dynamics simulations. Phys. Condens. Matter. 2004, 16, 705-713. [CrossRef]

57. Barrera, G.D.; de Tendler, R.H.; Isoardi, E.P. Structure and energetics of Cu-Au alloys. Model. Simul. Mater. Sci. Eng. 2000, 8, 1-37. [CrossRef]

58. Metadjer, N.; Laref, A.; Khelifa, B.; Mathieu, C.; Bresson, S.; Aourag, H. Tight-binding calculation of structural properties of bulk Cu3Au and its corresponding clusters. Superlatt. Microstruct. 2001, 30, 21-28. [CrossRef]

59. Pfeiler; Sprusil, B. Atomic ordering in alloys: Stable states and kinetics. Mater. Sci. Eng. A 2002, 324, 34-42. [CrossRef]

60. Johansson, H.; Linde, J.O. Röntgenographische und elektrische Untersuchungen des CuAu-Systems. Ann. Phys. 1936, 25, 1-48. [CrossRef]

61. Kuczynsk, C.; Hochman, R.F.; Doyama, M.J. Study of the Kinetics of Ordering in the Alloy AuCu. Appl. Phys. 1955, 26, 871-878. [CrossRef]

62. He, R.; Wang, Y.C.C.; Wang, X.X.; Wang, Z.; Liu, G.; Zhou, W.; Wen, L.; Li, Q.; Wang, X.; Chen, X.; et al. Facile synthesis of pentacle gold-copper alloy nanocrystals and their plasmonic and catalytic properties. Nat. Commun. 2014, 5, 4327. [CrossRef]

63. Bracey, C.L.; Ellis, P.R.; Hutchings, G.J. Application of copper-gold alloys in catalysis: Current status and future perspectives Chem. Soc. Rev. 2009, 38, 2231-2243. [CrossRef] [PubMed]

64. De Abajo, F.J.G.; Manjavacas, A. Plasmonics in atomically thin materials. Faraday Discuss 2015, 178, 87-107. [CrossRef] [PubMed]

65. Tuan, T.Q.; Dung, N.T. Molecular dynamics factors affecting on the structure, phase transition of Al bulk. Phys. B Condens. Matter 2019, 570, 116-121.

66. Dung, N.T.; Van, C.L. Effects of Number of Atoms, Shell Thickness, and Temperature on the Structure of Fe Nanoparticles Amorphous by Molecular Dynamics Method. Adv. Civ. Eng. 2021, 2021, 9976633.

67. Dung, N.T.; Phuong, N.T. Factors affecting the structure, phase transition and crystallization process of AlNi nanoparticles. $J$. Alloy. Compd. 2020, 812, 152133.

68. Tuan, T.Q.; Dung, N.T. Effect of heating rate, impurity concentration of $\mathrm{Cu}$, atomic number, temperatures, time annealing temperature on the structure, crystallization temperature and crystallization process of Ni1-xCux bulk; $x=0.1,0.3,0.5,0.7$. Int. J Mod. Phys. B 2018, 32, 1830009. [CrossRef]

69. Dung, N.T. Influence of impurity concentration, atomic number, temperature and tempering time on microstructure and phase transformation of Ni1-xFex (x= 0.1, 0.3, 0.5) nanoparticles. Mod. Phys. Lett. B 2018, 32, 1850204. [CrossRef]

70. Long, V.C.; Van, D.Q.; Dung, N.T. Ab Initio Calculations on the Structural and Electronic Properties of AgAu Alloys. ACS Omega 2020, 5, 31391-31397. [CrossRef]

71. Dung, N.T.; Phuong, N.T. Molecular dynamic study on factors influencing the structure, phase transition and crystallization process of $\mathrm{NiCu}_{6912}$ nanoparticle. Mater. Chem. Phys. 2020, 250, 123075.

72. Dung, N.T.; Cuong, N.C.; Van, D.Q. Study on the Effect of Doping on Lattice Constant and Electronic Structure of Bulk AuCu by the Density Functional Theory. J. Multiscale Model. 2020, 11, 2030001.

73. Dung, N.T.; Van, C.L.; T,ălu, Ș. The Structure and Crystallizing Process of NiAu Alloy: A Molecular Dynamics Simulation Method J. Compos. Sci. 2021, 5, 18 .

74. Trung, V.Q.; Duong, T.T.; Tran; Chinh, N.T.; Vuong, N.T.; Hien, N.; Vinh, P.V.; Dung, N.T.; Duc, N.D.; Phuong, N.T. DFT Prediction of Factors Affecting the Structural Characteristics, the Transition Temperature and the Electronic Density of Some New Conjugated Polymers. Polymers 2020, 12, 1207.

75. Chiang, I.C.; Chen, D.H. Synthesis of monodisperse FeAu nanoparticles with tunable magnetic and optical properties. Adv. Funct. Mater. 2007, 17, 1311-1316. [CrossRef]

76. dos Santos, V.; Kuhnen, C.A. Electronic structure and magnetic properties of Ni/Au and Ni/Cu bilayers. Thin Solid Film. 1999, 350, 258-263. [CrossRef]

77. Togasaki, N.; Okinaka, Y.; Homma, T.; Osaka, T. Preparation and characterization of electroplated amorphous gold-nickel alloy film for electrical contact applications. Electrochim. Acta 2005, 51, 882-887. [CrossRef]

78. Molenbroek, A.M.; Nørskov, J.K.; Clausen, B.S. Structure and reactivity of Ni-Au nanoparticle catalysts, J. Phys. Chem. B 2001, 105, 5450-5458. [CrossRef]

79. Antoniak, C.; Gruner, M.E.; Spasova, M.; Trunova, A.V.; Roemer, F.M.; Warland, A.; Krumme, B.; Fauth, K.; Sun, S.; Entel, P.; et al. A guideline for atomistic design and understanding of ultrahard nanomagnets. Nat. Commun 2011, 2, 528. [CrossRef] [PubMed]

80. Sun, S.H.; Murray, C.B.; Weller, D.; Folks, L.; Moser, A. Monodisperse FePt nanoparticles and ferromagnetic FePt nanocrystal superlattices. Science 2000, 287, 1989-1992. [CrossRef]

81. Gao, Y.; Shao, N.; Pei, Y.; Zeng, X.C. Icosahedral crown gold nanocluster $\mathrm{Au}_{43} \mathrm{Cu}_{12}$ with high catalytic activity. Nano Lett. 2010, 10, 1055-1062. [CrossRef]

82. Sun, Q.; Ren, Z.; Wang, R.; Wang, N.; Cao, X. Platinum catalyzed growth of NiPt hollow spheres with an ultrathin shell. J. Mater. Chem. 2011, 21, 1925-1930. [CrossRef]

83. Wang, R.M.; Zhang, H.Z.; Farle, M.; Kisielowski, C. Structural stability of icosahedral FePt nanoparticles. Nanoscale 2009, 1, 276-279. [CrossRef] 
84. Wang, R.M.; Dmitrieva, O.; Farle, M.; Dumpich, G.; Acet, M.; Mejia-Rosales, S.; Perez-Tijerina, E.; Yacaman, M.J.; Kisielowski, C. FePt icosahedra with magnetic cores and catalytic shells, J. Phys. Chem. C 2009, 113, 4395-4400. [CrossRef]

85. Green, I.X.; Tang, W.J.; Neurock, M.; Yates, J.T. Spectroscopic observation of dual catalytic sites during oxidation of CO on a $\mathrm{Au} / \mathrm{TiO}_{2}$ catalyst. Science 2011, 333, 736-739. [CrossRef]

86. Rafii-Tabar, H.; Sutton, A.P. Long-range Finnis-Sinclair potentials for f.c.c. metallic alloys. Philos. Mag. Lett. 1991, 63, 217-224. [CrossRef]

87. Kimura, Y.; Qi, Y.; Cagin, T.; Goddard, W.A., III. The quantum Sutton-Chen many-body potential for properties of fcc metals. In CalTech ASCI Technical Report 003; California Institute of Technology: Pasadena, CA, USA, 1998.

88. Doye, J.P.K.; Wales, D.J. Global minima for transition metal clusters described by Sutton-Chen potentials. New J. Chem. 1998, 22, 733-744. [CrossRef]

89. Qi, Y.; Cagin, T.; Kimura, Y.; Goddard, W.A. Molecular-dynamics simulations of glass formation and crystallization in binary liquid metals: Cu-Ag and Cu-Ni. Phys. Rev. B 1999, 59, 3527. [CrossRef]

90. Sutton, A.P. Long-range finnis-sinclair potentials. Philos Mag. Lett. 1990, 61, 139-146. [CrossRef]

91. Januszko, A. Phonon spectra and temperature variation of bulk properties of $\mathrm{Cu}, \mathrm{Ag}$, $\mathrm{Au}$ and $\mathrm{Pt}$ using Sutton-Chen and modified Sutton-Chen potentials. J. Phys. Chem. Solids 2015, 82, 67-75. [CrossRef]

92. Yue, Q.; Tahir, Ç.; Yoshitaka, K.; Goddard, W.A., III. Viscosities of Liquid Metal Alloys from Nonequilibrium Molecular Dynamics. J. Comput.-Aided Mater. Des. 2001, 8, 233-243.

93. Kart, H.H.; Tomak, M.; Cagın, T. Thermal and mechanical properties of $\mathrm{Cu}-\mathrm{Au}$ intermetallic alloys. Model. Simul. Mater. Sci. Eng. 2005, 13, 657-669. [CrossRef]

94. Todd, B.D.; Lynden-Bell, R.M. Surface and bulk properties of metals modelled with Sutton-Chen potentials. Surf. Sci. 1993, 281, 191-206. [CrossRef]

95. Verlet, L. Computer "experiments" on classical fluids. I. Thermodynamical properties of Lennard-Jones molecules. Phys. Rev. B 1967, 159, 98-103. [CrossRef]

96. Sankaranarayanan, S.K.R.S.; Bhethanabotla, V.R.; Joseph, B. Molecular dynamics simulation study of the melting of Pd-Pt nanoclusters. Phys. Rev. B 2005, 71, 195415. [CrossRef]

97. Tsuzuki, H.; Branicio, P.S.; Rino, J.P. Structural characterization of deformed crystals by analysis of common atomic neighborhood. Comput. Phys. Commun. 2007, 177, 518-523. [CrossRef]

98. Honeycutt, J.D.; Andersen, H.C. Molecular dynamics study of melting and freezing of small lennard-jones clusters. J. Phys. Chem. 1987, 91, 4950-4963. [CrossRef]

99. Ali, R.; Kamran, B. Identification of crystal structures in atomistic simulation by predominant common neighborhood analysis. Comput. Mater. Sci. 2017, 126, 182-190.

100. Ackland, G.-J.; Jones, A.-P. Applications of local crystal structure measures in experiment and simulation. Phys. Rev. B 2006, 73 , 054104. [CrossRef]

101. Hoover, W.G. Canonical dynamics: Equilibrium phase-space distributions. Phys. Rev. A 1985, 31, 1695-1697. [CrossRef]

102. Xu, Y.H.; Wang, J.P. Direct Gas-phase synthesis of heterostructured nanoparticles through phase separation and surface segregation. Adv. Mater. 2008, 20, 994-999. [CrossRef]

103. Nose, S.A. Unified formulation of the constant temperature molecular dynamics methods. J. Chem. Phys. 1984, 81, 511-519. [CrossRef] 